\title{
Development of technology elements for growing of perennial sorghum
}

\author{
Adamen, F. F. ${ }^{1}$ - Saplev, A. V. ${ }^{2}-$ Kudinov, S. V. ${ }^{2}$ \\ 'Kherson State Agrarian University, Crimea, Ukraine \\ ${ }^{2}$ Crimean Agrotechnological University, Crimea, Ukraine
}

\section{SUMMARY}

Optimal sowing time for perennial sorghum under irrigation is when soil temperature at the depth of sowing reaches up to $10-11{ }^{\circ} \mathrm{C}$, harvesting for the green mass has to be done when panicle is situated on the stem in 10 sm from the flag leaf and hight of cut must be $11 \mathrm{sm}$.

Keywords: watersupply of soil, value of waterdeficit, precipitation, irrigation, maize, systems of crop-rotation

\section{INTRODUCTION}

At present the main source of sugars for animals are cereal grasses. However the most wide-spread multi-hay-harvest cereals, sorghum plants, provide low economic efficiency, perennial grasses are winter type and provide only one hay harvest. According to the opinion of Uteush Yu.A., Shepel' N.A. perennial sorghum or Columbus grass (Sorghum almum Parodi) is very perspective in this respect (Утеуш, 1990; Шепель, 1994) and can provide up to 3-4 hay harvests (Утеуш and Лобас, 1996; Мельников, 1997).

Taking into account potential productivity, droughtresistence, salt resistence, Columbus grass can be cultivated not only at the arable lands but at the saline and low fertility soils. Nevertheless, perennial sorghum practically is not cultivated at all in Ukraine. One of the main causes of this - absence of growing technology. Scientific results for the development of its elements are presented in this article.

\section{PROGRAM AND METHODOLOGYOF RESEARCH}

Research had been conducted on the Parana variety at the experimental field of South Branch of NUBiP of Ukraine Crimean Agrotechnological University under conditions of south carbonate chernozem with irrigation. Experiments had been laid in fourfold replication. Discount area consisted of $62 \mathrm{~m}^{2}$. With main tillage was applied phosphorus $\left(210 \mathrm{~kg} \mathrm{ha}^{-1}\right)$, nitrogen has been applied with presowing tillage $\left(60 \mathrm{~kg} \mathrm{ha}^{-1}\right)$ and during following years - in spring at the beginning of vegetation after first and second hay harvest $\left(30 \mathrm{~kg} \mathrm{ha}^{-1}\right)$. Harvesting had been conducted separately at each allotment by mowing and weighing of obtained mass. Quality characteristics of green mass were being determined by methods which are standard for Ukraine.

\section{RESULTS OF RESEARCH}

One of the main elements of technology of cultivation is the sowing time. It had been established that the most productive proved to be the perennial sorghum that had been sown when soil temperature at the depth of sowing reached up to $10-11^{\circ} \mathrm{C}$ (Table 1). For Crimea - it is the third decade of April. Sowing time did not influence the quality of green mass (Table 2).

The minimal fodder cost price had been obtained with sowing of Columbus grass in the middle of third decade of April.

Final stage in the growing technology of agricultural plants if harvesting. In the experiment maximal productivity of Columbus grass had been obtained when harvested while panicle was situated in 30 and $10 \mathrm{sm}$ from the flag leaf and the cut hight $11 \mathrm{sm}$ (Table 3).

Influence of sowing time on perennial sorghum harvest

\begin{tabular}{lrrrr}
\hline \multirow{2}{*}{ Sowing time } & \multicolumn{3}{c}{ Harvest $\left(\mathrm{t} \mathrm{ha}^{-1}\right)$} \\
\cline { 2 - 5 } & 2008 & 2009 & 2010 & Sum for 3 years \\
\hline 15. 04. $\left(7-8{ }^{\circ} \mathrm{C}\right)^{*}$ & 66.2 & 61.5 & 56.4 & 184.1 \\
25. 04. $\left(10-11^{\circ} \mathrm{C}\right)^{*}$ & 73.5 & 71.4 & 66.2 & 211.1 \\
05. 05. $\left(12-14^{\circ} \mathrm{C}\right)^{*}$ & 56.9 & 53.4 & 48.2 & 158.5 \\
$15.05 .\left(15-16^{\circ} \mathrm{C}\right)^{*}$ & 47.5 & 44.5 & 40.7 & 132.7 \\
LSD $_{5 \%}$ & 5.9 & 4.9 & 4.4 & 20.1 \\
\hline
\end{tabular}

Note: *soil temperature at the sowing depth 
Quality of green mass and cost price of feed-protein units of perennial sorghum in dependence on sowing time (2008-2010)

\begin{tabular}{|c|c|c|c|c|c|c|}
\hline \multirow[b]{2}{*}{ Sowing time } & \multirow{2}{*}{$\begin{array}{c}\text { Feed units in } \\
1 \mathrm{~kg} \text { of fodder }(\mathrm{kg})\end{array}$} & \multicolumn{2}{|c|}{ For 1 feed unit there is $(\mathrm{g})$} & \multirow{2}{*}{$\begin{array}{l}\text { Output of feed-protein } \\
\text { units for } 3 \text { years }\left(\mathrm{t} \mathrm{ha}^{-1}\right)\end{array}$} & \multicolumn{2}{|c|}{ Cost price (hrivnas $\mathrm{t}^{-1}$ ) } \\
\hline & & $\begin{array}{c}\text { Digestible } \\
\text { protein }\end{array}$ & Sugars & & Green mass & $\begin{array}{c}\text { Feed-protein } \\
\text { units }\end{array}$ \\
\hline 15. 04. $\left(7-8{ }^{\circ} \mathrm{C}\right)^{*}$ & 0.181 & 74 & 152 & 27.8 & 79.6 & 528.0 \\
\hline 25. 04. $\left(10-11^{\circ} \mathrm{C}\right)^{*}$ & 0.182 & 73 & 153 & 31.8 & 58.1 & 427.8 \\
\hline 05. 05. $\left(12-14^{\circ} \mathrm{C}\right)^{*}$ & 0.184 & 74 & 153 & 24.3 & 77.5 & 505.1 \\
\hline 15. 05. $\left(15-16^{\circ} \mathrm{C}\right)^{*}$ & 0.184 & 74 & 156 & 20.3 & 87.7 & 572.2 \\
\hline $\mathrm{LSD}_{5 \%}$ & 0.1 & 6.1 & 14.3 & 2.5 & - & - \\
\hline
\end{tabular}

Note: *soil temperature at the sowing depth

Harvest of perennial sorghum during vegetation period in dependence on harvesting time and hight of cut $\left(\mathrm{t} \mathrm{ha}^{-1}\right)(\mathbf{2 0 0 8 - 2 0 1 0})$

\begin{tabular}{|c|c|c|c|c|}
\hline \multirow{2}{*}{ Hight of mowing (sm) } & \multicolumn{3}{|c|}{ Harvesting time } & \multirow{2}{*}{$\begin{array}{l}\text { Average on } \\
\text { the cut high }\end{array}$} \\
\hline & $30 \mathrm{sm}$ from the flag leaf & $10 \mathrm{sm}$ from the flag leaf & Tasseling of panicle & \\
\hline 7 & 63.6 & 64.6 & 66.0 & 64.8 \\
\hline 11 & 68.1 & 70.7 & 65.3 & 68.1 \\
\hline 15 & 59.9 & 67.4 & 61.5 & 62.9 \\
\hline 19 & 53.4 & 62.9 & 54.5 & 56.9 \\
\hline Medium on harvesting time & 61.3 & 66.5 & 61.8 & - \\
\hline
\end{tabular}

Note: $\mathrm{LSD}_{5 \%}$ for particular differences: $3.7 \mathrm{t} \mathrm{ha}^{-1}, \mathrm{LSD}_{5 \%}$ for harvesting time: $2.6 \mathrm{t} \mathrm{ha}^{-1}, \mathrm{LSD}_{5 \%}$ for the hight of cut: $3.0 \mathrm{t}$ ha ${ }^{-1}$

The lowest productivity had been registered with all the harvesting times with cut hight 19 sm while harvested during tasseling of panicle stage. Harvesting times and cut hight did influence the quality of obtained fodder: nutrients content increased in green mass with increasing of cut hight (Table 4).

Highest content of digestible proteins and sugars had been registered in the variant where harvesting was conducted while panicle was situated in $30 \mathrm{sm}$ from flag leaf and cut hight 19 sm. However the output of feed-protein units was the highest on those variants where harvesting had been conducted when panicle was situated in $10 \mathrm{sm}$ from the flag leaf with cut hight 11 and $15 \mathrm{sm}$.

Fodder with the minimal cost price had been obtained when harvested with panicle situated in $10 \mathrm{sm}$ from the flag leaf and cut hight $11 \mathrm{sm}$ (Table 5).

Quality of green mass of perennial sorghum in the dependence on harvesting time and cut hight (2008-2010)

\begin{tabular}{|c|c|c|c|c|c|}
\hline \multirow{3}{*}{ Harvesting time } & \multirow{3}{*}{ Cut hight (sm) } & \multicolumn{3}{|c|}{ Content } & \multirow{3}{*}{$\begin{array}{c}\text { Output of feed-protein } \\
\text { units }\left(\mathrm{t} \mathrm{ha}^{-1}\right)\end{array}$} \\
\hline & & \multirow{2}{*}{$\begin{array}{l}\text { In } 1 \mathrm{~kg} \text { of fodder } \\
\text { feed units }(\mathrm{kg})\end{array}$} & \multicolumn{2}{|c|}{ For 1 feed unit $(\mathrm{g})$} & \\
\hline & & & Digestible proteins & Sugars & \\
\hline \multirow[t]{4}{*}{$30 \mathrm{sm}$ from the flag leaf } & 7 & 0.177 & 97 & 172 & 10.6 \\
\hline & 11 & 0.175 & 100 & 176 & 11.3 \\
\hline & 15 & 0.171 & 103 & 180 & 9.9 \\
\hline & 19 & 0.166 & 107 & 182 & 8.7 \\
\hline \multirow[t]{4}{*}{$10 \mathrm{sm}$ from the flag leaf } & 7 & 0.194 & 82 & 156 & 10.9 \\
\hline & 11 & 0.192 & 84 & 162 & 11.9 \\
\hline & 15 & 0.191 & 87 & 167 & 11.5 \\
\hline & 19 & 0.190 & 90 & 170 & 10.8 \\
\hline \multirow[t]{4}{*}{ Tasseling of panicle } & 7 & 0.195 & 70 & 143 & 10.5 \\
\hline & 11 & 0.193 & 72 & 148 & 10.4 \\
\hline & 15 & 0.189 & 75 & 156 & 9.8 \\
\hline & 19 & 0.185 & 78 & 161 & 8.6 \\
\hline \multicolumn{2}{|c|}{$\mathrm{LSD}_{5 \%}$ for particular differences } & 0.006 & 3.1 & 4.0 & 0.9 \\
\hline
\end{tabular}


Cost price of perennial sorghum during the vegetation period in dependence harvesting time and cut hight (hrivnas $\mathrm{t}^{-1}$ ) (average for years 2008-2010)

\begin{tabular}{lcccc}
\hline \multirow{2}{*}{ Hight of mowing $(\mathrm{sm})$} & \multicolumn{3}{c}{ Harvesting time } & \multicolumn{2}{c}{$\begin{array}{c}\text { Average on } \\
\text { the cut hight }\end{array}$} \\
\cline { 2 - 4 } & $30 \mathrm{sm}$ from the flag leaf & 10 sm from the flag leaf & Tasseling of panicle & 468.50 \\
4 & 461.25 & 416.75 & 448.50 & 449.00 \\
11 & 435.00 & 394.00 & 449.50 & 425.75 \\
15 & 489.50 & 432.00 & 472.75 & 457.00 \\
19 & 550.75 & 466.25 & 459.75 & 496.50 \\
Average for harvesting time & 484.00 & 427.25 & - \\
\hline
\end{tabular}

\section{CONCLUSIONS}

Maximal productivity with minimal price cost of the fodder, perennial sorghum, which is being cultivated under irrigation, forms with sowing when soil temperature at the depth of sowing reaches up to $10-11^{\circ} \mathrm{C}$; with harvesting when panicle is situated on the stem in $10 \mathrm{sm}$ from the flag leaf and when hight of cut is $11 \mathrm{sm}$.

\section{REFERENCES}

Утеуш, Ю. А. (1990): Новые перспективные кормовые культуры. К. 192.

Шепель, Н. А. (1994): Сорго. Волгоград. 448.

Утеуш, Ю. А.-Лобас, М. Г. (1996): Кормові ресурси флори України. К. 218.
Мельников, М. М. (1997): Некоторые биологические особенности травы Колумба в связи с её интродукцией в кормопроизводство Крыма. Вопросы стабилизации и повышения эффективности АПК Крыма в исследованиях молодых учёных. Сб. научных трудов. Симферополь. 6-9. 
